\title{
Editorial
}

\section{Governments and Free Markets: Comparative or Strategic Advantage?}

Living in a global economy has turned out to be a supremely challenging experience.

The competition is fierce, the haves and havenots have already carved out their respective niches - the losers outnumber the winners - as always and with their hands down. Losers, and now even the entire loser nations and states, are being newly conceived, spawned and pacified in an apparently extravagant and endless abundance.

What is their comparative advantage? Patience? Capacity for suffering? Willingness to work for peanuts? Selling postcards? Selling their companies? Selling their countries? Selling their children? Selling themselves?

Comparative advantages are much harder to come by as we approach the year 2000 . They do not grow on trees or fall from heavens, they are not brought forth by Nature, as they used to. Comparative advantages have to be wrought, struggled for, nurtured and strengthened, they do not emerge on their own, and they abhore passive and hands-off playwright pseudostrategies of Waiting for Godot. Comparative advantages have become strategic advantages.

In a modern and knowledge-intensive global economy, it matters a lot whether a country produces (and exports) cow chips, potato chips or computer chips. In high-technology-based competitive environments, one can produce computer chips quite autonomously, without the benefits of producing the other 'chips'. But one cannot competitively produce the first two kinds without the benefits of the third one. So, only one kind of these 'chips' imparts the true economic advantage; only the most value or knowledge laden chip matters in

IOS Press

Human Systems Management 11 (1992) 173-176 the end. The rest is just 'sushi'.

Yet, Richard Darman, then Deputy Secretary of the Treasury, said in 1985 [1]: 'Why do we need a semiconductor industry? If our guys can't hack it, let them go.' So, they (and it) went: behold, the law of comparative advantage in the hands most nimble.

Assume that country A produces mostly cow chips or potato chips while country B produces mostly computer chips. For every $\$ 1$ million worth of its soybeans, chopsticks, sushi and waste paper, country A receives from B $\$ 1$ million worth of automobiles, camcorders, optical scanners and just-intime software. The trade balance is even in dollar terms: Look ma, no deficit.

But there is a huge deficit building up from such 'trade' [5]. The added value and knowledge deficits grow enormous, resulting in a long-term and often irreversible loss and downgrading of skills, wages, jobs and a country's precious knowledge base.

How much more a country's (and a firm's) output is worth than all its inputs of materials, labor and capital? How much or how little of value is added through its own production, business and management activities? Such are the right questions to ask. Obviously, selling natural stands of taiga trees adds little or no value while selling intelligentelectronics or pharmaceutical products adds significant value to the product. The devastating effects of trading dollar for dollar worth of such incommensurable 'goods' are not difficult to see.

The 'added value' is the amount of economic loss to society if the firm ceased to trade and its inputs were redispersed within the economy. In terms of added value as $\%$ of sales, Autodesk (33.9\%) leads in the U.S., Fuji (15.5\%) in Japan and Glaxo $(27.8 \%)$ in Britain [2]. 
That knowledge and knowledge-based products are crucial is not all that new. Even in the 19th century, James Naysmith, the inventor of the steam hammer, insisted: 'I believe that Free Trade in Ability has a much closer relation to national prosperity than even Free Trade in Commodities.' This is true especially and particularly today.

Surprisingly, it is this free trade in ability (knowledge) that is being curtailed: ideas, innovation, discussion, information and knowledge do not flow very freely. In fact, such crucial flows are being positively smothered and even sneered upon in Central Europe and Russia. Commodities are allowed to flow relatively freely (not fairly), even though they are incomparable in terms of their 'ability', i.e. quality and utility. So, in Central Europe especially, gravel, trees, beds and bodies are being 'traded' for computers, software and telecommunication systems. The sorry end of such 'economics' is bound to come swiftly. One side is slipping into abhorrent and unprecedented dependency, being cheered on by its ex-communists, while the other is off-shoring the socially and ecologically destructive 'productions'. Free trade in commodities combined with 'unfree' trade in abilities results in poverty, decline and degradation which breeds extremism, fascism and neocommunism. Bureaucrats at IMF and World Bank choose to call all such an 'economic transformation' and cheerfully prescribe patience, restriction and tightening of belts - to other people.

Yet, the times of the 19th century passive, natural or given comparative advantage are gone forever. It is now an almost medieval truism to emphasize that one could advantagously produce wine in Spain, bananas in Honduras, ice in Alaska and brown coal, gravel and unprocessed wood in Czechoslovakia. But where should one produce memory chips, decision-support software and selective laser sintering devices?

The answer is: anywhere. Spain, Honduras, Alaska and Czechoslovakia are not excluded - if they can reach for it, if they can get there first, if they do not sit on their hands, shut their eyes and plug their ears. Knowledge and skills-based comparative advantage is not a gift of God, Weather or Adam Klaus. Modern comparative advantage is strategic and thus it has to be taken. Initiating and helping with the capture of strategic industries and high added-value activities is a right task for wise, active and dynamic government.

Strategic advantage has to be created and pursued vigorously. Decision and resolve are important, time is crucial. To be 'there' first and to 'seed the clouds' first amounts to a huge comparative advantage in itself. Time to market and time to cash do matter. To hesitate, to wait for Godot of the 'market forces', to slide into economic passivity and inactivity can squander fragile and budding comparative advantages, anywhere.

True, most governments are passive, hands-off and largely incompetent shufflers and re-shufflers of budgets, spendings, rates and taxes. True, some governments still meddle, interfere and squander national resources through their bureaucracies, commands, controls and restrictions. But there are a few governments that have learned how to work with their economies by enhancing (not restricting) free markets, stimulate growth, support and develop competitiveness, invest in people and their infrastructure, produce knowledge and follow through on their achievements. Such governments 'seed the clouds.'

Superficially invoking and plagiarizing the greatness of Adam Smith, just for the purposes of camouflaging governmental passivity and incompetence, introduces a severe competitive disadvantage in most economies.

Governments are not simply watchdogs of business, nor are they isolated and separated from business; they are (or should be) partners with business. Their function should be clear and obvious: create and maintain the best possible conditions for business to continually improve its productivity, quality and competitiveness through high added-value activities. Creating such conditions is neither interference nor passivity: it demands competence, wisdom and knowledgeable action, i.e., governmental attributes that are definitionally and perennially in a short supply.

Among the most poignant examples of governmental incompetence are the recent admissions of Alan Greenspan, the chairman of Federal Reserve and one of the world's most influential central bankers. Chatting about the state of the U.S. economy, he stated: 'No models can explain the types of 
patterns we are having ... the tried and true methods of economic analysis and the old monetary tools just do not seem to be working ... the policy makers' methods for analyzing the American economy, developed and proved in the postwar period, are simply failing to guide the Fed ...' [3].

It is not enough to study savings rates, interest rates and deficits. What matters are the institutions and the nature of their relationships. The structure of the business-government relationships in the areas of education, technology, finance and banking is a crucial factor.

It is clearly better to do nothing than to tinker under the conditions of desperate ignorance, misunderstanding and frustration. But it is not fair for any government to let its country go, freely and voluntarily, down in the direction of cow chips. Governments should not tinker, interfere or apply their 'tried and true methods' that do not work. Governments should cooperate with business towards enhancing the competitiveness, quality and added-value competency of country's companies and institutions.

Governments do not 'pick winners' or 'cut off losers': that is neither their competency nor their business. Governments must create the conditions and environment where losers can become winners and winners are not forced to lose. Governments must help to enhance country's competitiveness through enhancing its added-value activities. Letting the country businesses 'float' aimlessly in the globally competitive sea is not 'pro business.'

Pursuing proper Added-Value Strategy for the country is Government's business. What would be some of the building blocks of such strategy?

1. No passive barring of imports, but active support and enhancement of exports. Not of any exports, but of high added-value goods and services. Not just 'free' trade, but equal access, fair trade and strategic advantage.

2. Not just balanced trade (in dollar terms) but a trade balanced in knowledge resources, added value and long-term appreciation. Dollar for dollar, it does make a difference whether they come from computer chips or cow chips.

3. Technology platform continually updated and strengthened through government-business research and development cooperation.
4. Tax and regulatory stimulation of long-term investment, economic growth, entrepreneurship, innovation, co-ownership and self-management.

5. Enhancing cooperation and collaborative competition, loosening 'anti-trust', curtailing monopolies and penalizing hierarchical command systems. Free markets and democracy have to flourish also within companies, not just 'outside the factory gates.'

6. Education, vocational training and technological literacy through business-government cooperation. Knowledge-based economy requires not just any education, but high added-value education, enhancing initiative, leadership, selfreliance and technological competence.

7. Competent government, which is not fragmented by catering to special interests, but unified in enhancing the country's competitiveness.

The invisible hand of the free market functions most efficiently in propagating and strengthening the already established patterns, not in introducing and initiating the new ones. So, the cow-chip player goes even more deeply into cow chips and the computer-chip player into computer chips. Consequently, the freest possible market is most effective if one is strong, rich and in the computer chips than if one is weak, poor and in the cow chips.

One cannot finance buying camcorders by selling trees. More precisely, one pays through the nose for such a 'it doesn't matter' non-policy.

The weak does not become stronger by freely competing with the strong: he is simply crushed. The poor does not become richer by freely competing with the rich: he is simply bought. The producer of cow chips does not start producing computer chips: he simply does not know how.

It's a little like with boxers. Those in their prime have to keep fighting, fully exposed to the toughest competition. Protecting the aging champions will not make them any stronger. But letting your youngest and most promising talent in with the infamous 'slugger' is most foolish and unfair, regardless the money.

The issue is not whether to protect or not, but whom, how, when and why. One should not protect the winners and one should not protect the losers. one should support those on their way up, adding knowledge and value, not protect those on their 
way down, losing value and degrading knowledge.

One must not prevent the best and the brightest from competing abroad. That is not a freemarket. So, do not limit your machine tool makers, optical fiber procurers and supercomputer producers from doing business abroad. You will lose them.

'Protection' cannot mean closing of borders, imposing tariffs and quotas, and increasing isolation. That is passive and static protection; quite hopeless. Protection must be active and dynamic: tax benefits, credit support, investment stimulation, information and knowledge transfer, R\&D support, education and privatization. It must primarily strengthen you, not just weaken the competition.

Free markets function best when their pumps are primed, their clouds seeded and their entrepreneurs and businessmen educated and encouraged in the added-value directions, from cow chips to computer chips.

Information, research \& development, education, vocational training, infrastructure, environmental management are all vital areas where great government could become a useful partner to the private sector.

If a country consistently trades low added-value goods for high added-value goods (soybeans for camcorders), both knowledge and added-value deficits quickly build up. Dollar trade deficit then inevitably follows (more and more soybeans for the same number of camcorders). If the country tries to cling to its standard of living, it has to borrow, thus aggravating both trade and knowledge deficits. The cause of the trade deficit is knowledge deficit, not the other way around. Removing the trade deficit is possible only through removing the knowledge deficit or by accepting a lower standard of living (less camcorders).

Similarly with the internal budget deficit. It is not a simple imbalance between receipts and spending: that could be remedied by a shrewd balancing of numbers that 'add up'. Its causes are deeper: it stems from the added-value and knowledge deficit: $74 \%$ of the U.S. workforce is employed in the services (low added value) and $8 \%$ is unemployed (zero added value), leaving only $18 \%$ of the workforce in manufacturing, extraction and agriculture (high added value) [4].

Increases in productivity and employment are conflicting and mutually exclusive goals if pursued in a static, non-growth economy [5].

Increasing the employment in the services will simply aggravate the added-value deficit; reducing the deficit technically (balancing taxes and spending) will not remove its cause. It will necessarily grow back even if successfully 'balanced' by accountants. There are only two long-term solutions: remove the added-value and knowledge deficits or accept a lower standard of living.

The competent governments have their jobs cut out for them: help create, maintain, enhance, supply and apply knowledge to add value. The incompetent governments are better to stay out, with their 'tried and true' methods of economic analysis.

\section{References}

[1] Robert Kuttner, 'Facing Up to Industrial Policy,' New York Times Magazine, April 19, 1992, pp. 22, 26 and 42.

[2] 'Scrambling to the top,' The Economist, September 7th, 1991, pp. 21-24.

[3] 'Fed Chief Says Economy Is Resisting Remedies,' New York Times, October 15, 1992.

[4] Milan Zeleny, 'Structural Recession in the U.S.A.,' Human Systems Management, 11 (1992) 1, pp. 1-4.

[5] Sigfrido Lichtenthal, 'The Recession and the Economics of Knowledge,' Human Systems Management, forthcoming.

\author{
Milan ZELENY \\ Graduate School of Business \\ Fordham University at Lincoln Center \\ New York, NY 10023 \\ U.S.A.
}

